DOI: $10.20472 / B M .2015 .3 .3 .004$

\title{
REMUNERATION MODELS IN OUTSOURCING SERVICES
}

\section{ARNO RADERMACHER}

\begin{abstract}
:
Remuneration models within the outsourcing business are almost used as accounting tools only. The lowest price is quite often the most relevant decision criterion. But the structures of these models have a significant regulating influence on the respective service. In the present paper different approaches to service billing and their impact on the services in outsourcing itself are considered. With the aid of approaches from principal-agent and transaction cost theories optimized remuneration models for different strategic objectives of the outsourcing company will be developed. In particular, the dependence of the optimal remuneration upon the cost structure of the service provider is proven.
\end{abstract}

\section{Keywords:}

outsourcing, remuneration, salary, principal-agent

JEL Classification: M52, J33

\section{Authors:}

ARNO RADERMACHER, Tomáš-Bat'a-University, Zlin, Germany, Email:

Radermacher-Family@t-online.de

\section{Citation:}

ARNO RADERMACHER (2015). Remuneration models in outsourcing services. International Journal of Business and Management, Vol. III(3), pp. 40-57., 10.20472/BM.2015.3.3.004 


\section{Introduction}

The unbroken continuing development of outsourcing services includes not only the services themselves, but also the entire associated management tools. In addition to the contractual definition of the service as well as various control instruments, the remuneration model plays an important role in order to optimize both the outsourced service, as well as the overall performance of the outsourcing company itself. In this case, the agreed remuneration model should support the goals of the outsourcing company in the best possible way. This can be achieved by establishing an optimal incentive structure within the executing service provider company, based on the targets of the outsourcing company.

In recent decades, a large number of different payment models have been established in the outsourcing market. The most important of these models are shown in the following table.

\begin{tabular}{|c|c|c|}
\hline Term & Description and Characteristics & Comment \\
\hline $\begin{array}{l}\text { Fixed Price / } \\
\text { Lump Sum }\end{array}$ & $\begin{array}{l}\text { The service shall be remunerated at a fixed price per time } \\
\text { unit }\end{array}$ & $\begin{array}{l}\text { fixed remuneration / } \\
\text { lump sum }\end{array}$ \\
\hline $\begin{array}{l}\text { Transaction- } \\
\text { Based } \\
\text { Billing }\end{array}$ & Single output units are paid at fixed prices & $\begin{array}{l}\text { Variable remuneration; if } \\
\text { necessary coupled with } \\
\text { quality criteria }\end{array}$ \\
\hline Bonus/Malus & $\begin{array}{l}\text { Variable additional component on top of a basic salary. } \\
\text { The result of the service (e.g. in time/in budget) will be } \\
\text { additionally rewarded or sanctioned based on the } \\
\text { achievement of specific objectives }\end{array}$ & $\begin{array}{l}\text { Fixed remuneration with } \\
\text { variable risk reward } \\
\text { parts }\end{array}$ \\
\hline $\begin{array}{l}\text { Service } \\
\text { Level }\end{array}$ & $\begin{array}{l}\text { The remuneration is based on pre-defined specifications } \\
\text { (eg in terms of performance /output or the provided quality } \\
\text { of service) }\end{array}$ & $\begin{array}{ll}\text { Variable } & \text { remuneration; } \\
\text { should always be } \\
\text { coupled with quality } \\
\text { criteria }\end{array}$ \\
\hline $\begin{array}{l}\text { Balanced } \\
\text { Score Cards }\end{array}$ & $\begin{array}{l}\text { Remuneration model similar to the service level based } \\
\text { remuneration; also strategic objectives are taken into } \\
\text { account. Usually, objectives and progress of the four } \\
\text { categories financials, customers, internal processes and } \\
\text { employees are considered }\end{array}$ & $\begin{array}{l}\text { Fixed or variable } \\
\text { remuneration with risk } \\
\text { reward parts }\end{array}$ \\
\hline Value Based & $\begin{array}{l}\text { Value-based remuneration; depends on the achievement } \\
\text { of certain targets (e.g. added value, savings, } \\
\text { performance, etc.) }\end{array}$ & $\begin{array}{l}\text { Fixed or variable } \\
\text { remuneration with risk } \\
\text { reward parts. } \\
\text { A pure risk reward } \\
\text { remuneration is possible }\end{array}$ \\
\hline $\begin{array}{l}\text { Share-in- } \\
\text { Savings }\end{array}$ & $\begin{array}{l}\text { Remuneration is solely based on efficiency gains and cost } \\
\text { savings generated by the outsourcer as part of its service } \\
\text { to the outsourcer }\end{array}$ & $\begin{array}{l}\text { Variable risk } \\
\text { remuneration }\end{array}$ \\
\hline Gain Sharing & $\begin{array}{l}\text { Remuneration is solely based on the profits of the } \\
\text { outsourcing company }\end{array}$ & $\begin{array}{l}\text { Variable risk reward } \\
\text { remuneration }\end{array}$ \\
\hline
\end{tabular}

Table 1: Own illustration based on Bitkom [2006], pp. 33-39

Addendum: In the real economy, we find a number of other individual remuneration models, which are derived from a mixture of the models listed above. 
For our further analysis we want to reduce the number of different remuneration models to the following basic patterns:

- Fixed price (lump sum)

- Input oriented remuneration (e.g. Variable effort remuneration)

- Output oriented remuneration (performance-based pay)

$>$ piece based remuneration (output-related)

$>$ earnings or profit sharing

Since a clear customer-contractor relationship exists on the basis of negotiated agreements between outsourcer and service provider, it is self-evident to make use of the basic ideas of the New Institutional Economics. Especially the ideas of Transaction Costs Theory and Principal-Agency Theory will be applied.

Therefore at this point the main features of the above theories will be listed.

Transaction cost economics ${ }^{1}$

- Restricted rational decisions; since full information is not given

- Barter relations (transactions) are not free of cost

- Involvement of institutions and contracts; includes the economic justification of institutions (organizations, companies)

- tendency of market participants to behave opportunistically

The transaction costs are determined by the expression of the ${ }^{2}$

- Transaction dimensions

- Specificity / asset specificity

- Parametric and behavioral uncertainty

- Frequency

- Transaction atmosphere

- Strategic importance

"Agency Theory studies the delegation problem, the mechanism used by a Party $A$ (Principal) to motivate another Party B (Agent) to do something costly to Party $B$, but interesting for Party $A$.

- Principal has less information than the Agent concerning the realization of the task itself (information asymmetry) $=>$ hidden information problem. ${ }^{3}$

- Principal cannot observe the negotiations, intentions and activities of the Agent => hidden action problem.

- Agent and Principal tend to have conflicting interests, as both strive for their individual maximum gain "

Cited from Geraldi [2007]

For the business model Outsourcing applies:

- Principal is the outsourcer

- Agent is the service provider

\footnotetext{
see Williamson [1971], pp. 113-114; Williamson [1981], pp. 553ff; Krause [2008], p.78

2 see Nienhüser/Jans/Köckeritz [2012], pp. 4-6;

and: wirtschaftslexikon24.com ,Transaktionskostentheorie

3 see Maskin/Tirole [1990]: showing the unusual model where the principal is fully informed.

${ }^{4}$ Aside from Geraldi [2007] see Grossman/Hart [1983]
} 
Although the principal-agency theory usually proceeds with asymmetric information ${ }^{5}$, here we consider the following information and risk profiles:

- Case 1: Principal has full information about the effort of the service provider

- Case 2: Principal has incomplete information about the effort of the service provider

Below we let the cost of information acquisition (whether full or incomplete) primarily unconsidered. In reality, the outsourcer (principal) however, must take this effort into account. This effort, which is found behind words like retained organization, and reporting or monitoring costs, in reality represent a significant cost component for the entire business case for outsourcing arrangements.

We also assume that the labor input (effort or expenditures) of the service is positively correlated with the production function and the financial performance (at least the earnings) of the outsourcer. The higher the effort of the service provider, the higher the economic output of the outsourcer (and as much as possible also the economic result).

The production function generally has diminishing marginal returns. I.e. additional units of effort invested by the service provider, in principle will generate lower production growth by each step. ${ }^{6}$

We also need to consider that might and dependency relations of an outsourcer/service provider structure are not identical in all facets with the popular principal-agent-structures. In contrast to the principal-agent-structure in which in theory we have a 1:1 relationship (and in the reality a 1: $n$ relationship) between principal and agent or between shareholder and manager:

$>$ the individual service provider usually has a number of employers (i.e. several principals $=>\mathrm{m}: \mathrm{n}$ relationship)

$>$ the service provider (agent) might have any risk preference ${ }^{7}$

$>$ we cannot assume that the outsourcer (principal) is a risk-taker / risk-seeker ${ }^{8}$

This results in the preferred remuneration models of outsourcer and service provider here shown for different states of information and risk preferences of the involved parties. The proof of these preferences is done later in this paper.

\footnotetext{
${ }^{5}$ The principal doesn't know the input (working effort, et al) of the agent. The agent always has more information about the production or service process than the principal.

${ }^{6}$ In the scientific view we often see concave production functions, i.e. function curves with falling marginal earnings. About the entirety of the production functions, this may be true. In the real economy, however, we often find convex regions within the production function (e.g. due to synergies or economies of scale). I.e. the invest of an additional unit of effort results in a disproportionate increase in production.

7 In contrast to the common representations of the principal-agent scenarios in which the agent is assumed to be risk-averse.

8 The principal (at least as a shareholder) is usually considered to be a risk taker. As an outsourcer, this cannot be taken for granted, as the outsourcer often depends much more from the service provider. Therefore the outsourcer often operates risk averse in the market.
} 


\section{Outsourcer has complete information about the effort (input) of the service provider}

\begin{tabular}{|c|c|c|c|}
\hline $\begin{array}{l}\text { Sexvice-Pro- } \\
\text { vider } \\
\text { Outsourcer }\end{array}$ & Risk avers & Risk neutral & Risk taker \\
\hline Risk avers & $\begin{array}{l}\text { O: Variable (Effort- } \\
\text { oriented) / } \\
\text { SP: Fix Salary }\end{array}$ & $\begin{array}{l}\text { O: Variable (Effort -oriented) } \\
\text { SP: Indifferent }\end{array}$ & $\begin{array}{l}\text { O: Variable (Effort - } \\
\text { oriented) / } \\
\text { SP: Output-oriented }\end{array}$ \\
\hline Risk neutral & $\begin{array}{l}\text { O: Variable (indifferent) / } \\
\text { SP: Fix Salary }\end{array}$ & $\begin{array}{l}\text { O: Variable (indifferent) / } \\
\text { SP: Indifferent }\end{array}$ & $\begin{array}{l}\text { O: Variable (indifferent) / } \\
\text { SP: Output-oriented }\end{array}$ \\
\hline Risk taker & $\begin{array}{l}\text { O: Variable (Output- } \\
\text { oriented) / } \\
\text { SP: Fix Salary }\end{array}$ & $\begin{array}{l}\text { O: Variable (Output-oriented) } \\
\text { SP: Indifferent }\end{array}$ & $\begin{array}{l}\text { O: Variable (Output- } \\
\text { oriented) / } \\
\text { SP: Output-oriented }\end{array}$ \\
\hline
\end{tabular}

Table 2: Own elaboration, own data

O: Outsourcer / SP: Service Provider

2. Outsourcer has incomplete information about the effort (input) of the service provider (asymmetric information)

\begin{tabular}{|c|c|c|c|}
\hline $\begin{array}{l}\text { Service-Pro- } \\
\text { vider } \\
\text { Outsourcer }\end{array}$ & Risk avers & Risk neutral & Risk taker \\
\hline Risk avers & $\begin{array}{l}\text { O: Variable (Output- } \\
\text { oriented) / } \\
\text { SP: Fix Salary }\end{array}$ & $\begin{array}{l}\text { O: Variable (Output-oriented) } \\
\text { SP: Effort-oriented }\end{array}$ & $\begin{array}{l}\text { O: Variable (Output- } \\
\text { oriented) / } \\
\text { SP: Output-oriented }\end{array}$ \\
\hline Risk neutral & $\begin{array}{l}\text { O: Variable (Output- } \\
\text { oriented) / } \\
\text { SP: Fix Salary }\end{array}$ & $\begin{array}{l}\text { O: Variable (Output-oriented) } \\
\text { SP: Effort-oriented }\end{array}$ & $\begin{array}{l}\text { O: Variable (Output- } \\
\text { oriented) / } \\
\text { SP: Output-oriented }\end{array}$ \\
\hline Risk taker & $\begin{array}{l}\text { O: Variable (Output- } \\
\text { oriented) / } \\
\text { SP: Fix Salary }\end{array}$ & $\begin{array}{l}\text { O: Variable (Output-oriented) } \\
\text { / } \\
\text { SP: Effort-oriented }\end{array}$ & $\begin{array}{l}\text { O: Variable (Output- } \\
\text { oriented) / } \\
\text { SP: Output-oriented }\end{array}$ \\
\hline
\end{tabular}

Table 3: Own elaboration, own data

O: Outsourcer / SP: Service Provider

\section{The Expected Utility function}

For our observation we use a 'von Neumann-Morgenstern utility function' as a basis [expected utility function]. I.e. the benefits result from the benefit of individually expected values (see Maskin/Tirol [1990], p 383):

$\mathrm{U}(\mathrm{a}, \mathrm{v}, \mathrm{\alpha})=\mathrm{E}[\mathrm{u}(\mathrm{a}, \mathrm{\alpha})]=\sum_{i=1}^{n} p_{\mathrm{i}} \cdot u\left(a, \alpha_{\mathrm{i}}\right)$

with a: activity (effort, input) of the service provider v: remuneration (usually the money transfer from principal to the service provider);

can also be negative, e.g. in case of penitent fee agreements 
$\alpha$ : random variable, which affects the success of activity a (parametric uncertainty $)^{9}$

p: probability of success

For our example of a service outsourcing, now we have to determine what different events can exist for the outsourcer, but also for the service provider, to decide between. Assuming that product and market will already be determined, in the following we only consider:

- remuneration models (the duties of the outsourcer): - High remuneration vs. Low remuneration (up to the reservation salary) ${ }^{10}$

- Fixed remuneration vs. Variable remuneration (depending on input/effort or depending on the results)

- Input models (the obligations of the service provider): - Minimum effort vs. Intensive effort

For the further investigation it is also assumed that the outsourcer can influence the input of the service provider (his effort or his expenditure) only with the selected remuneration model. ${ }^{11}$

While the activity a of the service provider is positively correlated with the commercial success of the outsourcing company, $\alpha$ affects the overall success of a service completely independent upon a and purely arbitrarily ${ }^{12}$.

Thus, the production function $f(a)$ the outsourcer is given as follows:

$$
f(a)=\alpha \cdot p(a) ; \quad \text { with } p(a) \text { as technical production function }
$$

with $\alpha=g(t)$ as time-dependent random function

and $\alpha>0$

In addition, the underlying trend in $f(a)$ can be assumed to be a monotonically increasing function. Because of the random effects $\alpha$ in $f(a)$ we have to admit deviations for this monotonically increasing function $\mathrm{f}(\mathrm{a})$. Nevertheless, a higher input of the service provider generates, ceteris paribus, better results of the provided service and, consequently a higher output that will ideally go together with a higher business performance of the outsourcer ${ }^{13}$.

\footnotetext{
${ }^{9}$ Corresponds to the parametric uncertainty within the transaction cost theory and "referred to the uncertainty of future environmental conditions and their effect on the transaction", see Nienhüser/Jan/Köckeritz [2012], p 5

${ }^{10}$ Maskin/Tirol [1990], pp 386ff.

${ }^{11}$ In the real business process the outsourcer has more opportunities to influence the input of the service provider. Here, for example benchmark processes, participation in market surveys, short contract periods, etc.

${ }^{12}$ Within the random factors that act with $\alpha$ on the success of a, we can sum up the environmental conditions such as trade cycles, competition, political (in-)stability, etc.

${ }^{13}$ Cases of declining business success (profit) of the principal in parallel to increasing output will not be considered yet.
} 


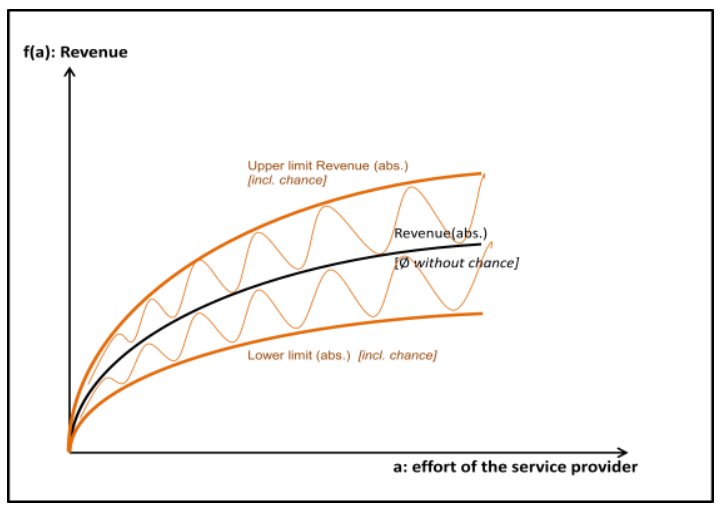

Graph 1: Revenue functionSource: Own graph

The graph above illustrates the influence of chance on the overall result of the service (revenue). The random factors can act both positively and negatively on the overall results, however the effect is subject to the fundamentally positive influence of additional work units of the service provider.

Based on the above shown functional definition, now we want to analyze the effects on the optimal remuneration structure.

\section{Optimal remuneration with Complete Information}

\subsection{The Principal / Outsourcer}

Since the outsourcer has complete information about the activities of the service provider, he can make his payment dependent on just these activities (effort). He can reward good performance and he can penalize poor performance accordingly. With this in mind it can be assumed that the outsourcer should choose a remuneration model with variable effort remuneration.

This recommendation takes validity, regardless of the risk preference of the outsourcer.

At this point, for a better understanding, we go into the definition of risk preference:

We assume that an investor has assets (or wealth) of 100 asset units (AU). He has an investment opportunity in which he can double his assets or completely lose with $50 \%$ probability. The expected value of this investment corresponds exactly to the origin of wealth:

$$
E=50 \% \times 200 A U+50 \% \times 0 A U=100 A U
$$

- Risk-averse: The investor will not adopt the investment opportunity; the risk of total loss outweighs the prospect of a higher wealth. The expected utility function of the risk-averse investor is concave

- Risk-neutral: the investor is indifferent between his two options - investment or nothing;

The expected utility function of the risk-neutral investor is linear

- Risk-taker: The investor will adopt the investment opportunity; the prospect of a higher wealth outweighs the risk of total loss; The expected utility function of the investor's risk-taking is convex 


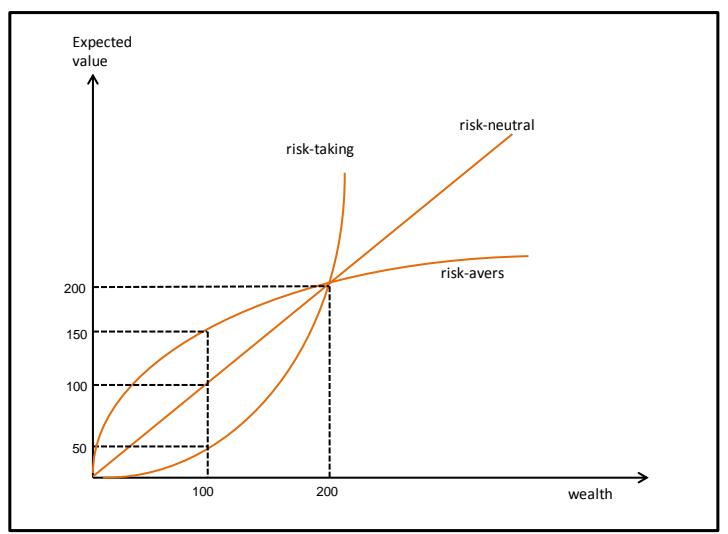

Graph 2: Risk preference Source: Own illustration

In the above representation of the different risk profiles can clearly be seen that the risk-taking investor, compared with the risk-neutral and the risk-averse investors, will generate only low value out of a low wealth increase, whereas his expected value will increase disproportionately with increasing wealth.

$$
\begin{array}{ll}
\text { Expected utility risk-averse: } & U(E)=50 \% \times 160 A U+50 \% \times 0 A U=80 A U \\
\text { Expected utility risk-neutral: } & U(E)=50 \% \times 200 A U+50 \% \times 0 A U=100 A U \\
\text { Expected utility risk-taking: } & U(E)=50 \% \times 260 A U+50 \% \times 0 A U=130 A U^{14}
\end{array}
$$

The risk-averse outsourcer will weigh all the Pro's and Con's, he receives with the variable effort/input remuneration compared to other remuneration models. With a variable effort-input-based remuneration he bears the sole financial risk ${ }^{15}$, but unlike other remuneration models with this type of remuneration he may also exert direct influence on the services of the agent. Risk aversion will cause a great value for this type of outsourcer produced by control and management. Therefore he prefers the variable effort/input remuneration ${ }^{16}$. For the risk-averse outsourcer the absolute highest win is less important than a sure win. He will therefore seek opportunities to secure his values, and he will accept associated expenses for control. Due to his complete information the outsourcer can more effectively intervene in the production processes compared to the output-based remuneration. With the output-based remuneration he would waive this benefit without obtaining a direct equivalent for it. But the risk-taking outsourcer will prefer an output-based remuneration already here. $\mathrm{He}$ is seeking the maximum profit that he can increase by low control costs. In addition due to his complete information and by given outsourcing contracts with short contract periods he can also promptly react to poor performance. In case of risk neutrality both actors, the outsourcer and the service provider, might be indifferent ${ }^{17}$. Their decision will significantly depend on the values of expected output and control costs.

The statement made above to the preference of the variable effort/input remuneration was made without consideration of the random function a (i.e. the environmental conditions). The influence of $\alpha$ counteracts the direct influence of the outsourcer on the effort/input of a service provider - exercised over the effort remuneration - and can lead to other preferred remuneration models, notably to output-based models ${ }^{18}$.

\footnotetext{
${ }^{14}$ Risk Avers: U" < 0; Risk Neutral: U" = 0; Risk Taker: U" >0

${ }^{15}$ whereas the service provider (agent) will be paid according to his effort. His salary will grow with his growing effort.

${ }^{16}$ E.g. in comparison to a profit sharing model

${ }^{17}$ Remark: Outsourcer will be indifferent between an output-oriented or an effort-oriented variable remuneration only

${ }^{18}$ The higher the influence of chance is on the output, the lower will be the interest of the outsourcer to pay the service provider purely by his effort.
} 
a thereby affects both the preference of the outsourcer as well as the preference of the service provider.

\subsection{The Agent / Service Provider}

With strong a outsourcer and service provider will prefer contradictory remuneration models. In a competitive environment this contradiction between outsourcer and service provider needs to be resolved through a compromise solution (risk sharing). In monopoly or oligopoly markets, however, the outsourcer would be able to transfer these risks unilateral to the service provider ${ }^{19}$.

The following diagram illustrates this conflict situation:

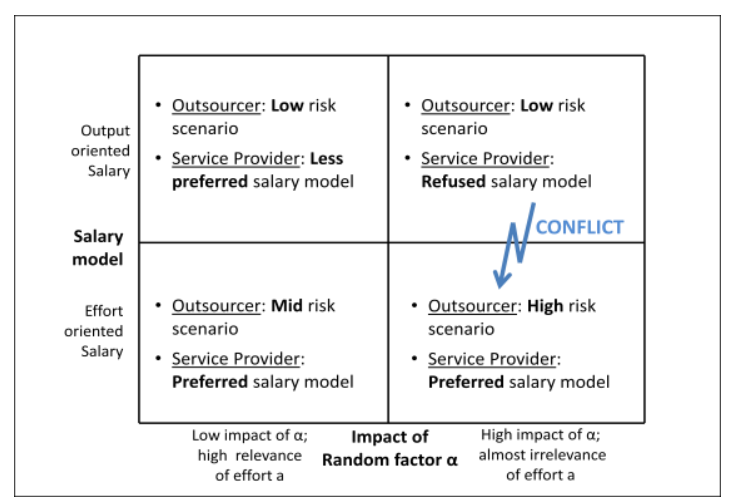

Graph 3: Preferred salary modelsSource: own illustration

Besides the type of remuneration also the level of remuneration will have a significant impact on the performance and the effort/input of the service provider. The service provider orients himself on the marginal revenue of his services. In case of rational behavior, he will increase his effort up to its optimum total return.

This will be illustrated in the following graph:

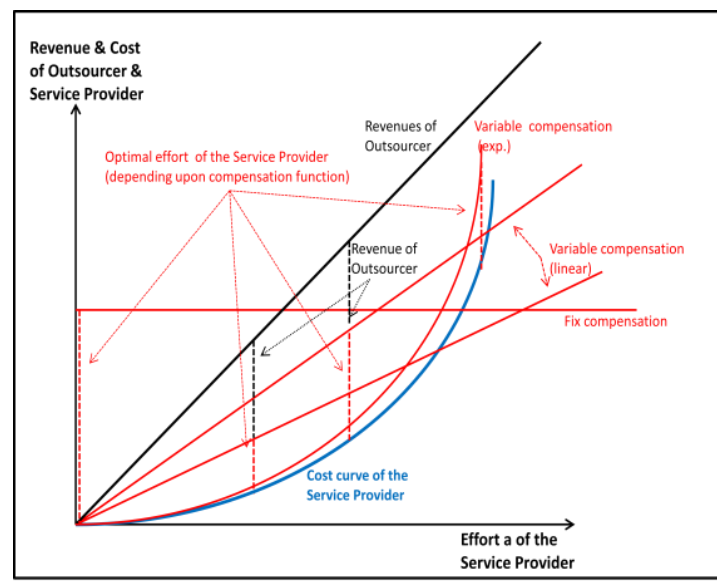

Graph 4: Remuneration modelsSource: Own illustration

The direct influence on the level and structure of the remuneration model is up to the decision of the outsourcer only. In the above graph, three different remuneration structures are shown:

- Fixed remuneration

\footnotetext{
19 see Mendius/Wendeling-Schröder [1991], p. 64, p. 181, pp. $228 f f$ et al. see Freiling [1995], p. 3, pp. 39ff, pp 146ff
} 
- Linear variable remuneration

- Exponential variable remuneration

The turnover function $U(a)$ of the outsourcer here is shown linear for the ease of understanding.

In our example, production, sales and earnings depend solely and directly from the input of the service provider (effort a). Therefore, we first consider the optimization process of the service provider.

In a fixed remuneration model there is no monetary incentive for the service provider to invest any effort, at least not for investing high effort. In this case, the outsourcer needs to apply other means to get an adequate performance from the service provider. The fixed remuneration model therefore is of very limited sense in the perspective of the outsourcer ${ }^{20}$.

The situation is different for the linear variable expense remuneration model. Here, the service provider can optimize his own profit $P_{S}$ [Remuneration - Own cost, i.e.: $\mathrm{t}(\mathrm{a})-\mathrm{C}_{\mathrm{s}}(\mathrm{a}) \mathrm{]}$. Within graph 4 this gain corresponds to the distance between the linear remuneration curve and the convex cost curve of the service provider.

In the above graph two different linear remuneration curves are shown. They show how the maximum profit of the service provider (at optimal effort: the red dashed vertical) and also his effort a will increase with a higher level of remuneration, at the same time, however, the profit of the outsourcer decreases (black dashed vertical).

The profit $\mathrm{P}_{\mathrm{O}}$ of the outsourcing company consists of the turnover $\mathrm{U}(\mathrm{a})$ [product quantity multiplied with the price, i.e.: $f(a) \cdot p(a)$ ] reduced by the remuneration to be paid $t(a)$ :

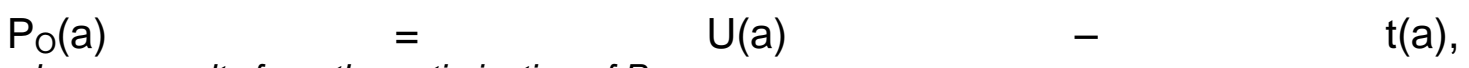

where a results from the optimization of $P_{S}$.

Therefore, the outsourcer would need to know the cost curve $\mathrm{C}_{S}$ of the service provider in order to maximize his own profit. However, knowledge of $\mathrm{C}_{\mathrm{S}}$ is usually not available for the outsourcer ${ }^{21}$. Therefore, the outsourcer can only make assumptions in order to optimize his own profit $\mathrm{P}_{\mathrm{O}}$.

With a variable remuneration structure, that is modeled with increasing distance to the cost curve $\mathrm{C}_{S}$ of the service provider (in graph 4 it would be the exponential variable remuneration), the outsourcer could cause the service provider to increase his input. As can be seen in the graph, the increase in remuneration, however, might already equalize the revenues $\mathrm{U}(\mathrm{a})$ of the outsourcer at an early stage. The maximum profit for the outsourcing companies, we find at the point with the largest distance between turnover $U(a)$ and the remuneration function $t(a)$. This point might become very low and therefore the exponential variable remuneration might become inferior to other variable remuneration models.

\footnotetext{
${ }^{20}$ But the real economic life shows constellations where a fixed salary will be the best solution - at least for a dedicated task and for a defined period of time; e.g. research or engineering services.

${ }^{21}$ Even in the observed scenario with Complete Information the outsourcer will only know the effort a of the service provider, but he will not know his cost function.
} 
It is clear, therefore, that the variable effort remuneration compared to the fixed remuneration is indeed the more appropriate remuneration option, since it honors the effort of the service provider in a variable manner. An exponential remuneration function should only grow very moderately, and should not cut the yield curve already at low output. I.e. t"(a) should be as low as possible. More importantly, which can be derived from graph 4 , is the recognition that the optimization of remuneration and profit $\mathrm{P}_{\mathrm{O}}$ is totally dependent on the cost curve $\mathrm{C}_{S}$ of the service provider. However, the cost curve $\mathrm{C}_{\mathrm{S}}$ is not at all or only partially known to the outsourcer.

The outsourcer cannot even circumvent this problem by selecting a remuneration structure that involves the service provider at the profits of the outsourcing company. This variant is not explicitly included in the above graph, but it corresponds to the turnover function $U(a)$ and the linear variable remuneration function. With increasing turnover $\mathrm{U}(\mathrm{a})$ and rising profit $\mathrm{P}_{\mathrm{O}}(\mathrm{a})$ the remuneration $\mathrm{t}(\mathrm{a})$ of the service provider will increase too. But he will, however, continue to align his effort at the maximum difference between $t(a)$ and his cost curve $C_{s}$. The profit of the outsourcer thus remains below the market opportunities - given a satisfactory product demand.

The remaining optimal choice for the outsourcer is therefore based on:

- The selection of the service provider based on his cost function $\mathrm{C}_{\mathrm{S}}$

- The influence of the outsourcer on the cost function $\mathrm{C}_{\mathrm{S}}$, e.g. by smoothing the cost curve with training, automation, etc.

A cost function $\mathrm{C}_{\mathrm{S}}$, linear or better concave up to high ranges of effort/input, will provide increasing profits for the service provider at rising effort and through this mechanism an increasing production output and therefore rising profits $\mathrm{P}_{\mathrm{O}}$ for the outsourcer.

Conclusion: The outsourcer should try to have the most possible and most accurate information about the cost function of the service provider, in order to optimize and increase his own profit! In this case, the profit sharing remuneration model is clearly recommended ${ }^{22}$.

The usual evaluation process within outsourcing decisions with almost and exclusively relying on the remuneration function of the service provider only (or the prices of outsourced services) is thus a significant deficiency in the decision-making process. The unilateral view of the cost of services, and the negligence of the internal cost function of the service provider, not only in theory but also in practice, leads to bad or completely wrong outsourcing decisions ${ }^{23}$.

Therefore let's consider the service provider once again in more detail.

A problem with the choice of the remuneration model 'variable expense remuneration', of course, also arises if it is contrary to the risk profile of the service

\footnotetext{
22 In that case it's necessary to regard the costs on transparency provisioning associated with the determination of profits. The entire production chain and the accounting should be disclosed to the service provider in order to guarantee a fair determination of profits. However, this often fails already because of political and strategic will of the outsourcer, or because of information restrictions at the outsourcer, as well as by the high costs connected with the disclosure, interpretation and control of the entire accounting.

${ }^{23}$ Among others based on own experience of the Author within the IT services area
} 
provider ${ }^{24}$. A risk-averse service provider aims ideally for a fixed price, while a risktaking service provider should prefer performance-based remuneration models with sufficient upside/profit opportunities ${ }^{25}$. In both cases, the service provider will try to shape (increase or decrease) his own input/effort in a way, that the additional income (and his expected value) is exactly equal to its additional effort. In a fixed-price model that value optimization - as already stated above - results in the tendency of effort reduction, since the service provider will always receive the same remuneration irrespective of its own effort. The outsourcer who has complete information, can even observe this effort reduction, but within the existing contractual terms with a fixed fee his influence on the invested effort of the service provider is very limited. Since the outsourcer is aware of this interrelation, he will probably not even provide to a riskaverse service provider his preferred fixed price model. These systemic divergent interests will lead medium and long term to significant problems within the relationship between service providers and outsourcers and contribute to the effect that existing outsourcing relationships often lose attractiveness over their lifetime.

For the here considered case of complete information, in the real business we have to suppose, that information is not a free of charge good. Information will become available by reporting or control $^{26}$. The control of the service provider for the outsourcer is combined with own effort, i.e. direct cost, while reporting through the service provider will induce indirect costs due to higher remuneration. For the following analysis we assume a control function with decreasing marginal utility. This assumption can be considered as generally accepted. On the other side there is no general statement possible about the cost function of control itself. The cost function of control can have linear, but also concave or convex (exponential) structures, as well as jumps and non-linear/non-monotone curves.

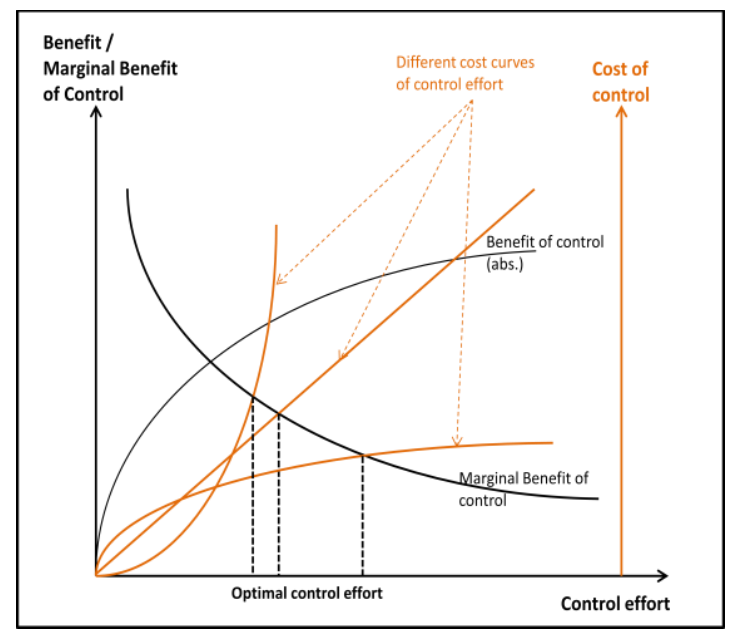

Graph 5: Cost of control Source: Own illustration

Assuming that the benefits of control can be equated with economic benefits for the outsourcer, in the above graph, the importance of efficient control mechanisms is easily recognizable. A rational outsourcer will expand his control scope in maximum up to the intersection of control cost and marginal control utility. Effective controls, that are represented by flat (concave) cost curves allow higher control benefits and

\footnotetext{
${ }^{24}$ This is independent upon talking about a pure effort- or output-oriented, or a profit-oriented compensation. As far as the compensation model is selected by the outsourcer is conflicting with the risk profile of the service provider, the selected model is unlikely to be enforceable.

See Henneberger/Sousa-Poza/Ziegler [2007]: showing output oriented salaries and the change of risk behavior of companies and employees.

${ }^{26}$ In the following reporting and control will be summarized under the term control.
} 
thus the greater economic benefits for the outsourcer. For an optimal remuneration the outsourcer should have an incentive to choose a remuneration that supports efficient control mechanisms, or ideally already provides control information. When we look at our defined remuneration models, only the variable expense remuneration, due to its structure, will provide expenses neutral information to the outsourcer about the effort of the service provider. While the variable output remuneration at least allows some conclusions about the effort of the service provider (we expect a positive correlation between the effort of the service provider and the production results), a fixed fee model is totally unsuitable as it cannot derive any effort information ${ }^{27}$.

\section{Optimal remuneration with Incomplete Information}

In the case of incomplete information, we assume that the information is distributed asymmetric between Principal (outsourcer) and agent (service provider). I.e. the outsourcer has no direct information on the effort/input of the service provider and he cannot obtain that information. The outsourcer only can determine the output of the provided services. Consequently, the remuneration model chosen by the outsourcer should be output-oriented ${ }^{28}$, built fully variable in the ideal case. Suitable remuneration models are piece-based remuneration, transaction-based models, profit sharing, etc.

\subsection{The Principal / Outsourcer}

The preference of a variable output-oriented remuneration is, as in the case of complete information, independent upon the risk preference of the outsourcer, as the outsourcer has only this information. The risk-averse outsourcer does not want to wear the risk of poor workmanship or deficient performance of the service provider. Since he does not know and cannot control the input/effort of the service provider, he cannot influence this directly. In contrast to the completely informed outsourcer to his availability there is only the indirect influence on the effort of the service provider by rewarding the output (or by not rewarding).

Also for the risk-neutral and risk-taking outsourcers exists no economically understandable motivation - outside of exceptional scenarios ${ }^{29}$ - to choose the fixed instead of the variable remuneration. However, knowledge of the cost function $\mathrm{C}_{\mathrm{S}}$ of the service provider, might give to the outsourcer even here with incomplete information important knowledge for an optimal remuneration scheme, because the outsourcer can at least anticipate the behavior or the input optimization process of the service provider. Even if the outsourcer cannot explicitly control the effort of the service provider, it might be assumed that he largely acts rational in order to optimize his profit function $P_{S}$. However, if the outsourcer neither has any information about the effort $\mathrm{a}$, nor about the cost function $\mathrm{C}_{\mathrm{S}}$, again he remains with the orientation on the output of the services only.

For the further investigation we assume that the turnover function of the outsourcer is linear again: $U(a)=f(a) \cdot p(a)$

\footnotetext{
${ }^{27}$ See for that also the statements by Henneberger/Sousa-Poza/Ziegler [2007] about the correlation between control and measuring costs, and the probability for output or effort oriented salary models. Page 1: "piece rates are more likely in an environment with low monitoring costs"

${ }^{28}$ Fixed-price remuneration models would be banned here too, analogous to the reasoning already shown above. These models will long-term lead into an effort reduction at the service provider.

A fixed-price remuneration model (lump sum) can, for example, be useful in the situation of high price discounts, combined with a short duration of the service contract, and/or with high penalties in the situation of bad performance or nonperformance, as well as in other but similar conditions.
} 
Under the - for sure only little realistic - assumption of linear production costs, an unlimited market at constant market prices, and thus a fixed profit margin per unit, the outsourcer should have a basic interest in achieving the highest possible output. In order to increase the profit $\mathrm{P}_{\mathrm{O}}$ with rising turnover, the slope of the remuneration function of the service provider needs to be consistently lower than the slope of the turnover function U. Assuming increasing marginal costs of the service provider and therefore a convex cost curve of the service provider the outsourcer, ideally uses a linear or slightly convex remuneration function. This should ensure to the outsourcer a relatively high level of effort of the service provider for a great variety of possible cost functions of the service provider. Thus the service provider should reach his optimized profitability at a higher level of effort only.

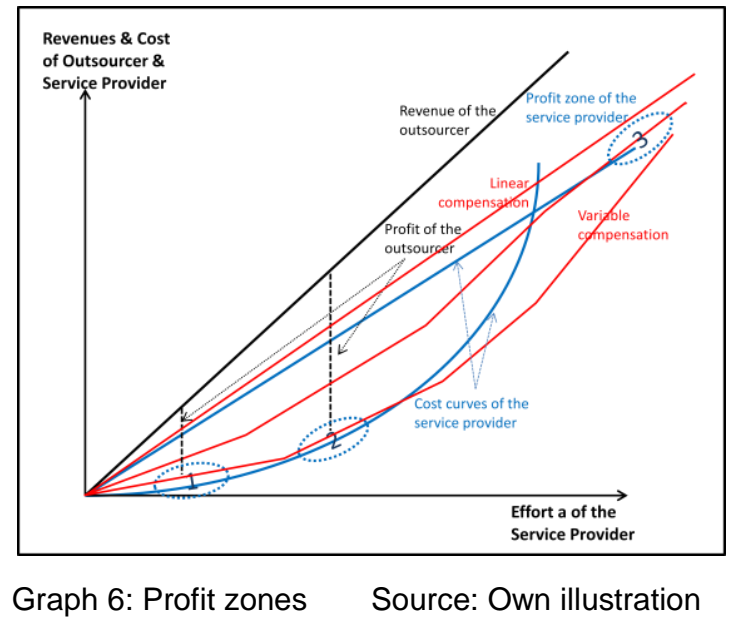

The graph No. 6 should illustrate this kind of complex variable remuneration, as well as the difficulties associated with that complex structure.

Within the two lower convex remuneration curves the outsourcer holds the remuneration low at low output, and increases the remuneration disproportionately with output increases. As a result, the service provider should be motivated to higher efforts. Depending on the cost curve of the service provider that easy thought of the outsourcer might lead to undesirable results, as we can see in the graph in the lower part of the cost curve $C_{S}$ and the remuneration curve $S_{S}$. The maximum profit of the service provider (the difference between the red remuneration curve $S_{S}$ and the blue cost curve $\mathrm{C}_{\mathrm{S}}$ ) can be identified in the profit zone 1 with a small turnover only and thus a small profit for the outsourcing company only. The much more profitable zone 2 will not be reached, since this is suboptimal for the service provider. At higher efforts, the costs of the service provider increase exponentially, and are very early above the remuneration curve.

Of specific interest is the observation of the profit zone 3 , which we can reach at a linear cost curve of the service provider. This shows us once again very clearly that the choice of a service provider with almost low/flat cost structures will be of great advantage. This can be achieved, for example, if the service provider has wellscaling structures and processes.

In this case the ideal combination would be of linear cost curves and remuneration curves of the service provider and for the turnover function of the outsourcer too.

This knowledge can be easily derived that the outsourcer should select a service provider, ideally, whose cost curve similar but significantly extends beneath its own revenue curve. In this case, the outsourcer chooses a remuneration which is between 
the two curves. The outstanding importance of knowing the cost curve of the service provider can also be seen here.

Based on that cognition it can be easily be derived that the outsourcer should in the best case select a service provider, whose cost curve has a similar course but significantly below its own turnover curve. In this case, the outsourcer may choose a remuneration which is between the two curves. The outstanding importance of knowing the cost curve of the service provider can also be seen here.

\subsection{The Agent / Service Provider}

Now, we should once again take a look at the service provider. He is aware that the outsourcer does not know his effort. However, the service provider knows the basic conditions of the production function $\mathrm{f}(\mathrm{a})$ :

- His higher labor input or effort leads, ceteris paribus, to better work results, i.e. to a higher output and higher yield of the outsourcer

- The random $\alpha$ affects the output regardless of any other factors

The service provider has limited control about the output of his own effort due to the random $\alpha$. In order to determine his optimum effort, the service provider should, as explained above, know the influence of chance or he needs to be able to estimate that influence at least.

An increase of the influence of chance $\alpha$ to the output $f(a)$ is associated with the declining influence of the effort of the service provider. If the random $\alpha$, in contrast to the effort of the service provider, greatly affects the output, this will reduce the incentive of the service provider to invest high effort ${ }^{30}$. For the service provider it is becoming increasingly meaningless, if he works or not. The production function is changing towards a horizontal line, while the utility function of the service provider is changing towards a decreasing function. By trend the service provider will therefore reduce his own effort.

If the service provider, within a situation of incomplete information, will optimize his utility function $U(a, v, \alpha)$, so he will increase his own effort, as already explained, only as long as the expected additional benefits exceed the costs of his additional effort. Here, the risk-averse service provider is the most sensitive to the influence of randomness $\alpha^{31}$. A service provider reacts with incomplete information in principle not different to the situation of complete information. However, since he is aware that his salary will only indirectly depend on its own effort (the outsourcer does not know his effort), he will make his decision dependent upon the degree of influence of this effort. With incomplete information the service provider will involve the influence of random $\alpha$ to a greater extent in his planning. In particular, the risk-averse service provider will try to achieve a secure remuneration, and thus he will prefer either a fixed-price or a performance-based remuneration ${ }^{32}$. In the latter remuneration model,

\footnotetext{
30 For the purpose of proof, we can use trends in socialistic planned economy models, as well as aspects of the discussions around 'Unconditional Basic Income'

In addition we can use the examples of research projects (R\&D) that are much less predictable; see: Froböse [2008], Keller [2013], page 3, H.J. Rheinberger: 'Really new things are by definition not predictable, and can therefore be induced only with significant limitation', page 6, Mühlbauer: 'Fundamental research is regarded as an incalculable risk of cost'

${ }^{31}$ As already shown above the expected utility of a risk-avers service provider for a high salary is lower than it is for a risk-taking service provider. The chance to get a high salary is of less value for the risk-avers service provider.

The service provider can announce by himself, how much effort he has invested; e.g. a cost+ compensation model. This situation often corresponds to the reality. The outsourcer can quite rarely trace the real cost of a service provider. The outsourcer needs to give one-sided confidence to the service provider.
} 
the effort information cannot be examined in incomplete information by the outsourcer. Only the risk-taking service provider, who always prefers high but even uncertain payments, will accept an output-oriented model. Only in this remuneration model the random can enhance the results and therefore the remuneration of the service provider.

Since the fix price and effort oriented salary models are of low interest for the Outsourcer there must be a trade-off provided by the service provider in order to achieve an acceptable situation for both parties. In reality we shouldn't expect to see a lot of fix price or effort oriented salary models in the case of Incomplete Information. These models will be too risky for the Outsourcer, and even for a risk taking outsourcer these models will not provide significant advantages. The need of compromises between Service Providers and Outsourcers might explain the existence of mixed models as well as it can explain simple employee salary models that are enriched by variable components.

In contrast to that the height of the remuneration itself will have minor influence on the selection of the best remuneration model; even if it has significant influence on the effort of the service provider, as we have shown above. The height will mainly be influenced by the competitive environment. In any case the height of the remuneration needs to cover the costs of the service provider in a way that it will incentivize the service provider to support the profit optimization of the Outsourcer in its best way.

\section{Optimal remuneration findings}

Transmission of the above proven statements will lead to the following remuneration recommendations:

- Outsourcing of reproducible known knowledge: since the result of the invested effort is almost secured, a piece-oriented remuneration structure should be selected, in order to create an incentive for a high input (effort) as well as for the invention of improved production processes.

- Outsourcing of innovation processes with the need of knowledge production: since the result of the invested effort is almost unknown, there is a huge risk for both parties to gain any benefit. The remuneration should be fix price oriented in order to transfer the risk from the agent to the principal, but should be combined with gain sharing components in case of success.

We have a reciprocal proportion: The saver the production process the more variable the remuneration.

In the above passages I have shown the different interests of service providers and Outsourcers, as well as different preferences that will depend upon the risk attitude of each single player. But the most important findings out of that analysis are:

- The outsourcer should provide a remuneration structure that has a similar profile than his own revenue structure.

- In order to identify the best fitting service provider the outsourcer should try to know the cost curves of potential service providers as good as possible.

- By knowing the risk profile of potential and also of already selected service providers the outsourcer can agree on a best mix of remuneration structures. 
Plain remuneration structures will in most cases not ensure a prosperous longstanding service relationship

\section{References}

BITKOM

[2006]

BITKOM: Public Sector: IT-Outsourcing / Public Private Partnerships; Leitfaden Public Privat Partnership und ITK-Outsourcing

$(09 / 2006)$

URL: https://www.bitkom.org/files/documents/PPP ITO E-Government fin.pdf

Freiling

Freiling, Jörg: Die Abhängigkeit der Zulieferer: Ein strategisches Problem; Gabler Edition Wissenschaft, 1995; ISBN 978-3-663-08369-6

Froböse

Froböse, Rolf: Wichtige Entdeckungen basieren auf Zufällen; in: Die Welt, 11.07.2008 URL: $\quad$ http://www.welt.de/wissenschaft/article2203948/Wichtige-Entdeckungen-basieren-aufZufaellen.html

Garen

Garen, John E.: Executive Remuneration and Principal Agent Theory; In: The Journal of Political Economy, Vol. 102, No. 6, Dec. 1994, pp. 1175-1199 URL:

http://classwebs.spea.indiana.edu/kenricha/Oxford/Archives/Oxford\%202006/Courses/Governance/Art icles/Garen\%20-\%20Executive\%20Remuneration.pdf

Geraldi

Geraldi,

Joana,

G.:

New

[2007] URL: http://www.uni-siegen.de/fb11/ist1/forschung/new institutional economics summary.pdf

Grossman/Hart

Grossman, Sanford J.; Hart, Oliver D.: An Analysis of the Principal-Agent problem; in: Econometrica, Vol. 51, No. 1 (Jan., 1983), pp. 7-45; Published by: The Econometric Society URL: http://classes.maxwell.syr.edu/ecn611/GrossmanHart83.pdf

Henneberger/Sousa-Poza/Ziegler

Henneberger, Fred; Sousa-Poza, Alfonso; Ziegler, Alexandre : Performance Pay, Sorting, and Outsourcing; IZA Discussion Paper No. 3019, August 2007 URL: $\underline{\text { http://d-nb.info/985576510/34 }}$

Keller[2013]

Keller, Martina: Prof. Dr. med. Zufall, in: Zeit-Online,

URL: http://www.zeit.de/2013/30/entdeckungen-medizin-geschichte-zufall

Krause

[2008]

Krause, Eric: Methode für das Outsourcing in der Informationstechnologie von Retail Banken Logos

ISBN $978-3-8325-1967-4$ Verlag, Berlin, 2008

Maskin/Tirole

Maskin, Eric; Tirole, Jean: The principal-agent relationship with an informed Principal: The case of private values; Econometrica, Vol. 58, No. 2 (March, 1990), 379-409 URL: http://classes.maxwell.syr.edu/ecn611/MaskinTirolel90.pdf

Mendius/Wendeling-Schröder Mendius, Hans Gerhard; Wendeling-Schröder (Hrsg.): Zulieferer im Netz - zwischen Abhängigkeit und Partnerschaft: Neustrukturierung der Logistik am Beispiel der Automobilzulieferung; Köln, BundVerlag, 1991 (Die andere Arbeitswelt; Bd. 3); ISBN 3-7663-2116-1

Nienhüser/Jans/Köckeritz

Nienhüser, Werner; Jans, Manuel; Köckeritz, Martin: Grundbegriffe und Grundideen der Transaktionskostentheorie - am Beispiel von "Make or Buy"-Entscheidungen über 
Weiterbildungsmaßnahmen; Universität URL: https://www.uni-due.de/apo/GrundbegriffeTAKT.pdf

Williamson

Williamson, Oliver E.: The Vertical Integration of Production: Market Failure Considerations, in: American Economic Review 61 (May, 1971): pp. 112-123

Williamson

Williamson, Oliver E.: The Economics of Organization: The Transaction Cost Approach, in: American Journal of Sociology, Vol. 87, No. 3, 1981, pp. 548-577. 